\title{
HOW TO EVALUATE UNIT PERFORMANCE
}

\author{
Thomas D. Scott
}

\author{
Submitted by \\ Jack Hiller, Chief \\ Presidio of Monterey Field Unit
}

\begin{abstract}
Approved as technically adequate and submitted for publication by Harold F. O'Neil, Jr., Director Training Research Laboratory
\end{abstract}

U.S. ARMY RESEARCH INSTITUTE FOR THE BEHAVIORAL AND SOCIAL SCIENCES 5001 Eisenhower Avenue, Alexandria, Virginia 22333-5600

Office, Deputy Chief of Staff for Personnel

Department of the Army

July 1984 